DOI No: http://dx.doi.org/10.29228/Joh.37414

Makale Türü: Araştırma makalesi

Geliş Tarihi: 23.09.2019

Kabul Tarihi: 20.06.2020

On-line Yayın: 31.08.2020
Article Type: Research article

Submitted: 23.09 .2019

Accepted: 20.06 .2020

Published Online: 31.08.2020

Atıf Bilgisi / Reference Information

Munis, M. E. (2020). The Relationship between University Students' Epistemological and Foreign Language Learning Beliefs. Journal of History School, 47, 24562785.

\title{
THE RELATIONSHIP BETWEEN UNIVERSITY STUDENTS' EPISTEMOLOGICAL AND FOREIGN LANGUAGE LEARNING BELIEFS $^{1}$
}

\section{Mehmet Emin MUNIS ${ }^{2}$}

\begin{abstract}
This study aimed to investigate the relationship between university students' epistemological and foreign language learning beliefs. In this regard, the study was conducted with the participation of 157 male and 145 female first-grade students studying at a university. The Epistemological Beliefs Questionnaire (EBQ) and the Beliefs about Language Learning Inventory (BALLI) were used to collect data. Frequencies, means, ttests and Pearson correlations were used to analyse the data. The results revealed that university students had sophisticated epistemological beliefs in terms of learning depends on effort and learning depends on ability sub-dimensions of the EBQ, while they were indecisive about one single truth sub-dimension. The study also revealed that the participants held various beliefs related to foreign language learning. There was a slight correlation between the students' epistemological and foreign language learning beliefs. The results also showed that the female students had slightly more sophisticated epistemological beliefs compared to males regarding learning depends on ability subdimension of the EBQ, while they did not differ in terms of their FLL beliefs.
\end{abstract}

${ }^{1}$ This study was produced from the author's master's thesis supervised by Prof.Dr. Jülide İNÖZÜ from Çukurova University.

2 Çă University, Institute of Social Science, English Language Education, MA Student. memunis@ hotmail.com, Orcid: 0000-0002-9928-0043 
The Relationship between University Students' Epistemological and Foreign Language Learning Beliefs

Keywords: Beliefs, Epistemological Beliefs, Foreign Language Learning Beliefs, Learning, Foreign Language Learning.

\section{Üniversite Öğrencilerinin Epistemolojik ve Yabancı Dil Öğrenmeye İlişkin İnançları Arasındaki İlişkinin İncelenmesi}

\section{Öz}

Bu çalışma, üniversite öğrencilerinin epistemolojik inançları ile yabancı dil öğrenimine ilişkin inançları arasındaki ilişkiyi incelemeyi amaçlamıştır. Bu bağlamda, çalışma, bir devlet üniversitesinde okuyan 157 kız 145 erkek birinci sınıf öğrencisinin katılımıyla gerçekleştirilmiştir. Nicel veri toplama araçları olarak Dil Öğrenme Inançları Envanteri ve Epistemolojik Inanç Ölçeği kullanılmıştır. Verilerin analizinde yüzdelikler, ortalamalar, t-testi ve Pearson r. Korelasyon testi kullanılmıştır. Çalışmada, üniversite öğrencilerinin ögrenme çabaya bağlıdır ve öğrenme yeteneğe bağlldır alt boyutlarında gelişmiş inançlara sahip oldukları, tek bir doğrunun var olduğuna inanç alt boyutunda ise kararsız oldukları tespit edilmiştir. Öğrencilerin yabancı dil öğrenimine ilişkin ise çeşitli inançlara sahip oldukları gösterilmiştir. Öğrencilerin epistemolojik ve yabancı dil inançları arasında zayıf bir ilişki tespit edilmiştir. Ayrıca, çalışmada, kız öğrencilerin öğrenme yetene ğe băglıdır alt-boyutunda erkek öğrencilere göre hafif düzeyde daha gelişmiş epistemolojik inançlara sahip oldukları, yabancı dil öğrenimine ilişkin inançlarında ise kız ve erkek öğrencilerin benzer inançlara sahip oldukları bulunmuştur.

Anahtar Kelimeler: İnançlar, Epistemolojik İnançlar, Yabancı Dil Öğrenimine İlişkin İnançlar, Öğrenme, Yabancı Dil Öğrenimi.

\section{INTRODUCTION}

With the tendency towards a learner-centred approach in education, factors affecting learners have started to take much interest. Foreign language learning (FLL) and teaching have gone through a similar paradigm shift (Moeller \& Catalano, 2015). Thus, what learners think about their learning attracted more attention. Many factors affect language learners and one of them is learner's belief. In a foreign language setting, learners surely hold a range of beliefs about FLL. These beliefs may be about lots of components of learning such as beliefs about general learning, FLL, teachers, themselves, their and their teachers' roles, and feedback given by teachers (Cotterall, 1995). In fact, language learners' surely have beliefs about learning in general called epistemological beliefs (EB) defined by Jehng, Johnson, and Anderson (1993) as intuitions shared socially associated with learning and the nature of knowledge. In this sense, language learners' beliefs about FLL may also be associated with and stem from their beliefs associated with general learning, namely their EBs. 


\section{Mehmet Emin MUNIS}

FLL settings are complicated areas of learning, in this regard, they are much more than applying reasonable and regular theories and principle since they are localized, situated-specific, and diverse (Hall, 2011). In the diversity of language classrooms, second or foreign language learners may form strong beliefs in regard to the language they want to learn; that is, the nature of the language, the difficulty, methods, achievement expectations, learning process, whether learning strategies are of use, and whether learning a language is a matter of talent (Bernat \& Gvozdenko, 2005). Learners come into a FLL environment with these existing beliefs; therefore, FLL beliefs can be defined as the predetermined ideas or opinions that individuals bring into their learning setting with the aim of learning a language other than their first one.

It is essential to understand learners' beliefs about FLL so as to understand learners' strategies and provide them with appropriate language teaching (Horwitz, 1999) as beliefs may ease and help or prevent learning (Schommer \& Walker, 1995). Examining learners' beliefs may help instructors understand learners' behaviours and classroom life better and more clearly (Hall, 2011). Learners' beliefs and motivation in FLL are interrelated and their beliefs about themselves, the target language and language learning may affect their behaviours (Hall, 2011).

For effective FLL to take place, learners' beliefs about general learning and those of about FLL need to be clearly understood and need to be explored. On the other hand, examining whether there exists a relation between learners' epistemological and FLL beliefs may widen language instructors' and researchers viewpoints for more effective language teaching. The lack of research regarding the possible existence of relationship between epistemic and FLL beliefs of language learners makes this present study different from other relevant studies as it attempts to expand on them by revealing both epistemic and FLL beliefs of language learners and whether a link between them exists. Therefore, we heed any attempts to elicit epistemological FLL beliefs of learners. Examining the relationship between these two kinds of beliefs will be valuable and contribute to FLL studies. The study has 4 research questions:

1. What are the EBs of university students?

2. What are the FLL beliefs of university students?

3. Is there a statistically significant relationship between the epistemological and FLL beliefs of university students?

4. Is there any significant difference in the epistemological and FLL beliefs of university students in terms of gender? 
The Relationship between University Students' Epistemological and Foreign Language Learning Beliefs

\section{LITERARY REVIEW}

\section{Epistemological Beliefs}

Learners bring along their individual and educational experiences and backgrounds, namely, their personal epistemological belief system, which reflects their opinions about learning consisting of their own beliefs, the beliefs of their parents, those of their teachers and others. These beliefs play an important role during learners' education process. For instance, a learner thinking that learning is innate may also feel suspicious about his/her talent in learning a subject. As Kardesh and Scholes (1996) put forward the role of learners' EBs in general strategic learning and problem solving in particular can be regarded as critical. In this regard, looking "insight into EBs may advance our understanding of human learning" (Schommer, 1990:503), and the knowledge of epistemological belief system of students and teachers is of high significance.

EBs refer to individuals' ideas about knowledge and the way they and other people come to know (Hofer \& Bendixen, 2012). EBs were evaluated as developmental stages until Schommer (1990), who then considered them as a multi-dimensional system. In this sense, developmental and multidimensional views are two ways, in which the evaluation of personal epistemology was carried out. The models and systems display that individuals' development with regard to the aspects of knowledge follow the road from immature beliefs to more sophisticated ones or from those of subjective to those of objective through number of stages and levels over time. Putting forward EBs as a system composed of unconnected multi-dimensional beliefs, Schommer $(1990,1993)$ proposed four belief dimensions as following: 1. Knowledge is described best as unconnected facts (simple knowledge), 2. Knowledge is unchanging (certain knowledge), 3. Learning ability is fixed at birth (innate ability), 4. Learning occurs quick or notat-all (quick learning).

\section{Epistemological Beliefs Studies}

From the late $20^{\text {th }}$ century to date, a growing focus has been on epistemological studies that go back to the studies by Perry $(1968,1970)$ who studied the EBs of university undergraduates and gave direction to many researchers to step in the investigation of the structure of EBs (Chan \& Elliott, 2004a). Research has focused on diverse aspects of EBs in the last decades and they were analysed from varied perspectives. Following the studies by Schommer $(1990,1993)$, a good deal of research has been done so far. The relation between learners' EBs and their comprehension of Maths text (Schommer, Crouse, \& Rhodes, 1992), the effects of individuals' EBs in problem solving, in-depth 
thinking and general strategic learning (Kardash \& Scholes, 1996), EBs and student motivation (Hofer, 1999), EBs and prediction of academic achievement (Cano, 2005), the effect of EBs on self-esteem (Özşeker, Canpolat \& Yıldız, 2011) and the connection between epistemic beliefs and critical thinking (Chan, $\mathrm{Hu} \& \mathrm{Ku}, 2011$ ) were some topics that were handled by researchers.

Considering epistemic beliefs, Kardash and Scholes (1996) revealed that in a problem solving, in-depth thinking and general strategic learning, individuals' EBs are critical and the degree of believing in certain knowledge determines one's level of abstracting changeable or certain conclusions from a text; the more one believes in accurate knowledge, the more he or she tends to abstract absolute consequences. Schommer (1993) carried out a study with high school students showing that epistemological progress was changeable and academic achievement could be forecasted by the belief in quick learning. Jehng et al., (1993) reported that learners' beliefs about learning may change when one gets further education. Deryakulu \& Büyüköztürk (2005) detected that the candidate teachers of classroom and social studies had more sophisticated beliefs than candidate computer-teachers.

Studies also concerned EBs in terms of gender difference. Schommer's (1993) study carried out a survey with high school learners showed that concerning the simple knowledge and certain knowledge dimensions, males and females had similar beliefs, but they were slightly unlike in their EBs related to the quick learning and fixed ability dimensions. Eren (2007) and Nayebi and Tahriri (2014) investigated EBs and they did not find a gender difference considering the participants' EBs. However, exploring first-year university students' EBs, Walker, Brownlee, Lennox, Exley, Howells and Cocker (2009) found significant gender difference regarding the beliefs about acquisition of truth.

In the past couple of years, studies concerning EBs examined the connection of EBs with varied aspects. Investigating the relation between teacher candidates' EBs and their academic attainment, Arslantaş (2016) found no difference in terms of gender based on the three factors of Epistemological Belief Scale. However, teacher candidates' epistemic beliefs were diverse depended upon their domains. Sevgi and Armağan (2017) investigated teacher candidates' EBs whether they differ considering of grade level, gender, and department. Findings also revealed that there wasn't significant difference between the teacher candidates' EBs of simple knowledge considering gender, department and grade level. The difference between their EBs of quick learning was not significant concerned gender and grade, but significant in terms of department. 
The Relationship between University Students' Epistemological and Foreign Language Learning Beliefs

The participants' beliefs about innate ability did not show significant difference in terms of department; however, there was significant relationship concerning gender and grade level. Ekinci (2017) conducted a study to indentify the connection between education teachers' EBs and their teaching and learning conceptions. The outcomes showed that the teachers had high level of beliefs regarding Authority/Expert Knowledge and Learning Effort/Process dimensions. Their level of beliefs concerning Innate/Fixed Ability dimensions was revealed to be moderate, while it was low about Certainty of Knowledge. They also had a high level of belief about the significance of and the requirement for questioning the learning process and dependency of learning on the effort by learners. It was indicated in the study that the teachers' EBs substantially is a predictor of their choices of teaching and learning conceptions. In another study, Pouratashia, Zhu and Zamani (2018) investigated the impacts of EBs on the agriculture students' motivation for achievement and academic attainment and they found that the students generally held developed EBs.

\section{Studies on Foreign Language Learning Beliefs}

The research concerning FLL beliefs is diverse and different aspects of FLL beliefs were handled. As the research suggests FLL beliefs have diverse characteristics. When the research is reviewed, it is seen that many characteristics of FLL beliefs are defined in the research. They displayed to be "context-specific" (Barcelos, 2000:319); "preconceived" (Horwitz, 1988:292); "dynamic and situated" (Pan\&Block, 2011:401) and different across culture (Truitt, 1995). On the other hand, they were found to be influenced by social and political context (Pan and Block, 2011; Naghdipour, 2014) and by previous learning experiences (Naghdipour, 2014). This diversity necessitates the investigation of language learners' FLL beliefs for better learning outcomes.

Many researchers naturally put much emphasis on FLL beliefs of learners as they are the most important figures of FLL medium (Matsuura, Chiba \& Hilderbrandt, 2001; Al-Zubaidi \& Sazalli, 2012; Naghdipour, 2014). Beliefs about FLL have been examined since the 1980s (C1sdik, 2014). Horwitz (1985, 1988) seems to be one of the prominent researchers concerning FLL beliefs by developing the BALLI, which has been utilized in a good many of studies so far to reveal both teachers and students' FLL beliefs in second and FLL contexts. Since Horwitz $(1985,1988)$, many studies have been realized aiming to explore and reveal learners' beliefs about FLL. Afterwards, the studies related to FLL beliefs have dealt with various features of FLL beliefs and a great number of studies have been realized (Horwitz, 1985, 1988, 1999; Cotteral, 1995; Kern 1995; Matsuura et al., 2001; Barcelos, 2010; Pan \& Block, 2011; Al-Zubaidi \& 


\section{Mehmet Emin MUNIS}

Sazalli, 2012; Naghdipour, 2014). For instance, Peacock (1999) concerned whether language beliefs affect proficiency, while Matsuura et al., (2001) examined undergraduate students' beliefs about communicative English in learning and teaching.

Regarding learners' beliefs concerning FLL, Fujiwara (2011) found that a great number of the respondents believed that learning English would make them have a brighter future associated with their career. Most of the participants were willing to have native speaker friends. In Bahadir's (2011) study the findings demonstrated that the participants valued intense repetition and practice in English. Examining Arab undergraduate learners of English, Al-Zubaidi and Sazalli (2012) demonstrated that the participants did not think English is difficult to learn and majority of them thought that everyone could learn a foreign language. A great number of the students were willing to practice English with someone speaking it.

Investigated middle-school students' language learning beliefs in Korea, Jennifer \& Park (2015) revealed that Korean middle-school students were willing to learn English and cultures. They were also eager to use and learn communicative strategies while learning English. However, they had negative beliefs about their ability in learning a language. Dincer (2017), through a metaphor analysis investigated learners' beliefs concerning speaking English and being good speaking in English. Results showed that learners believed that speaking in English was enjoyable and that effort was needed for speaking skill. However, most of the learners regarded speaking as a very difficult task. On the other hand, according to the participants, speaking well in English means speaking fluently and those who speak well are intelligent, privileged and hardworking. Investigating FLL beliefs of university vocational school students, the results of the research done by Şevik, Yalçın and Bostancıoğlu (2018) showed that the participants recognized the role and significance of English as an international language and a good knowledge of English would provide them with useful opportunities. An interesting and contradictory finding was that, although the participants generally believed that they didn't have a language aptitude, they also believed that a foreign language could be learned by everyone.

Research also concerned gender difference in terms of FLL beliefs. Bernat and Lloyd (2007) demonstrated that males and females shared common beliefs, but females agreed more that multi-linguals are very intelligent. Rad (2010) found gender difference and revealed that the male participants seemed to be more concerned about difficulty of FLL and communication strategy than females, but males were in a higher position for the rest of the factors. Daif-Allah (2012) found 
The Relationship between University Students' Epistemological and Foreign Language Learning Beliefs

males and females had similar FLL beliefs concerning the difficulty and the nature of FLL dimensions but significant gender differences related to other dimensions of the BALLI, while Yazic1 (2014) found that males and females shared similar beliefs. Considering gender difference, Zhou (2018) demonstrated that females were more motivated in learning English than males, while males considered English an easier language comparatively and they were more positive about their aptitude in target language learning.

\section{Epistemological Beliefs and Foreign Language Learning Beliefs}

An overall literature review on FLL demonstrates that the relationship between learners' FLL beliefs and EBs is rarely investigated. One of the studies concerning this relationship was carried out by Mori (1999) who investigated EBs and FLL beliefs of college students learning Japanese. The study revealed that individuals' belief in certain knowledge were transferred in FLL process, that is, those who believed in certain knowledge looked for coherency between mother tongue and target language. Learners' beliefs in quick learning and fixed ability demonstrated to be linked to their attitudes about taking risks while trying to use the foreign language for communication.

Another study in this area by Ziegler (2015) looked for the relation between EBs and vocabulary knowledge in FLL. The study revealed that good deal of students internalized sophisticated EBs related to vocabulary knowledge. The participants' beliefs about certainty and simplicity of knowledge dimensions were quite sophisticated.

A recently conducted study based on a descriptive and exploratory method by Nikitina and Furuoka (2018) aimed to determine the dimensions in language learners' personal epistemology of Russian language learning studying at a public university in Malaysia. An instrument named "Language Learners' Epistemic Beliefs" (LLEB) questionnaire was developed to conduct the study. The results showed that Russian language learners' EBs could be classified in five dimensions as Authority to knowledge, Nature of knowledge, Concentration, Hard work and Effort.

\section{METHOD}

\section{Context of the Study}

This study was carried out at a public university in the southeastern part of Turkey. General English is taught at the first year of the undergraduate and 


\section{Mehmet Emin MUNIS}

associate degree programs and departments for two terms as a compulsory course. The learners take English for two hours a week and four skills are intended to be taught during the class time.

\section{Research Design}

The study relied on a quantitative approach. Thus, quantitative data gathering tools were benefited from to investigate the epistemological and FLL beliefs of university students and the relationship between the two.

\section{Participants}

Totally 506 freshmen enrolled at a public university in the eastern of Turkey from varied faculties and vocational schools in 2016-2017 academic year were targeted to participate and respond the questionnaires. From this point of view, the first-grade students represented the population of the research and it was aimed to reach the entire population to conduct the questionnaires. There were 506 students ( 313 males and 193 females) enrolled in the programmes in the 2016-2017 academic year. Out of 506 first-grade students, 312 (162 females, 150 males) students were reached to fill in the questionnaires. However, 302 appropriately filled questionnaire forms for each scale were assessed.

\section{Instruments / Data Collection}

The gathered data through two scales, which were the Beliefs about Language Learning Inventory (the BALLI) and the Epistemological Beliefs Questionnaire (the EBQ). To reveal the EBs, the Turkish version of Schommer's (1990) EBQ, which was adapted by Deryakulu and Büyüköztürk (2005), and for FLL beliefs, Horwitz's (1988) BALLI were implemented. These scales are introduced in details in the following section.

\section{Epistemological Belief Questionnaire (EBQ)}

Schommer's (1990) EBQ consists of 63 items and four dimensions. Learners are expected to rate their agreement level by pointing for each item on the scale ranging from 1 strongly disagree to 5 strongly agree (Schommer, 1990, 1993; Hofer \& Pintrich, 1997; Deryakulu \& Büyüköztürk, 2005). The high scores obtained on the dimensions show one's naive beliefs; while the low score indicates sophisticated beliefs of the participants. However, in this study, the Turkish Version of Schommer's questionnaire adapted by Deryakulu and Büyüköztürk (2002) was implemented. The Turkish version of the scale consists of three dimensions with 34 items. The factors were named in accordance with Turkish culture as learning depends on effort (17 items with negative code), learning depends on ability (eight items), and there is only one truth (nine items). 
The Relationship between University Students' Epistemological and Foreign Language Learning Beliefs

The Cronbach Alpha was found to be .84 for the first dimension, .69 for the second, .64 for the third dimension and .81 in total. The items are assessed based upon each factor, not generally based on a total score of the EBQ (Deryakulu \& Büyüköztürk, 2002, 2005).

\section{The Beliefs about Language Learning Inventory (BALLI)}

The BALLI has 34 items and it was developed by Horwitz (1988) to assess student' views about language learning. Difficulty of Language Learning, Foreign Language Aptitude, The Nature of Language Learning, Learning and Communication Strategies and Motivations and Expectations are the five main areas of the BALLI.

Thirty-two items out of 34 are in a traditional five-point Likert scale arranging from 1 (Strongly Disagree) to 5 (Strongly Agree). However, two items $(4,14)$ of it aiming to reveal learners' ratings about the difficulty level of the target language they desire to learn, and the amount of time they think is necessary to learn a foreign language fluently, have different response scale. The BALLI is not evaluated on the basis of a total score; students' opinions for each item are assessed separately. The questionnaires were given to the respondents in Turkish because of their inadequate English language proficiency. Some studies including Başaran (2010), Cisdık (2014), and Geyimci (2015) used the Turkish version of the BALLI in Turkey.

\section{Procedure of the Study}

The questionnaire forms were copied and distributed to each student and they were asked to choose best option identifying their opinion best for each item. The researcher informed the respondents about how they were going to fill the questionnaires and their questions were answered. They were warned that they were required to rate for all the items of the questionnaires and not to leave any parts of the questionnaires unfilled.

\section{Data Analysis}

The SPSS 20.0 program was utilized in analyzing the data gathered by the scales. To analyze the findings, descriptive statistics, correlations, independent sample t-tests and Pearson correlation analysis were used. The mean scores, frequencies and independent sample t-test, which is made use of comparing the mean scores of two distinct and independent groups, were put to use to for analysis. Likewise, Pearson correlation analysis was benefited to reveal the correlation between the participants' epistemological and FLL beliefs. The EBQ 


\section{Mehmet Emin MUNIS}

was assessed based upon the total mean score for each factor. The BALLI, was not assessed on the base of a total score; each item was evaluated separately.

\section{Reliability}

The Cronbach Alpha scores for each scale were determined. The Cronbach Alpha Coefficient of correlation score for EBQ was 0.75. As the EBQ was analysed as dimensions the Cronbach Alpha scores for each dimension were determined, as well. For the first dimension the Cronbach Alpha score was .76, .72 for the second and.67 for the third dimension. On the other hand, Cronbach Alpha Coefficient of correlation for the BALLI was determined as 0.81. The BALLI was not analysed based on its dimension as it doesn't present a single score.

\section{FINDINGS AND RESULTS}

This study aimed to reveal epistemological and FLL beliefs of university students and whether there exist a relationship between the two kinds of beliefs. This part indicates the results gathered by the BALLI and the EBQ.

\section{Findings about the First Research Question: What are the EBs of University Students?}

The findings of each dimension of the EBQ were presented separately, the mean scores, standard deviations for each dimension was shown in tables. The results were assessed based upon the dimensions. The high total mean scores of the dimensions show unsophisticated beliefs, whereas, the low total mean scores indicate sophisticated epistemic beliefs of the participants.

\section{The EBs of the Learners in terms of Learning Depends on Effort Dimension}

\section{Table 1}

Learners' Beliefs about Effort in Learning

\begin{tabular}{llcll}
\hline Items* & $\mathrm{N}$ & $\bar{X}$ & $\mathrm{Sd}$. & Level of Agreement \\
\hline Total & 302 & 2,16 & 1,18 & Agree \\
\hline
\end{tabular}

(*): Negative items reverse coded: $1=$ Strongly Agree $(S A), 2=$ Agree $(A), 3=$ No Idea $(N I), 4=$ Disagree $(D) 5=$ Strongly Disagree $(S D)$

The total mean score $(M=2,16)$ for the factor 1 of the EBQ shows that the students generally agreed on the dimension. Namely, this shows that the participants believed that learning depends on effort. According to the EBQ, high mean scores signifies naïve beliefs, while low mean scores mean developed 
The Relationship between University Students' Epistemological and Foreign Language Learning Beliefs

epistemic beliefs. In that respect, the finding shows that the students had sophisticated beliefs and they believed that learning is based upon effort.

The EBs of the Learners in terms of Learning Depends on Ability Dimension

Table 2

Learners' Beliefs about Ability in Learning

\begin{tabular}{|c|c|c|c|c|}
\hline Items* & $\mathrm{N}$ & $\bar{X}$ & $\mathrm{Sd}$ & Level of Agreement \\
\hline Total & 302 & 2,39 & 1.22 & Disagree \\
\hline
\end{tabular}

(*): Positive items: $1=S D 2=D 3=N I 4=A 5=S A$

The total mean score for the factor 2 is 2,39 , which corresponds to Disagree level. This mean score indicates that the participants generally disagreed with learning depends on ability and they had sophisticated beliefs as low mean scores signify developed EBs.

\section{The EBs of the Learners in terms of Only One Truth Dimension}

Table 3

Learners' Beliefs about Singularity of Truth

\begin{tabular}{lllll}
\hline Items* & $\mathrm{N}$ & $\bar{X}$ & $\mathrm{Sd}$ & Level of Agreement \\
\hline Total Mean Score & 302 & 3,18 & 1.26 & No Idea \\
\hline
\end{tabular}

(*): Positive items: $1=S D 2=D 3=N I 4=A 5=S A$

The analyses for the factor 3 of the EBQ showed that the learners were undecided about most of the items. The total mean score $(M=3,18)$ shows this irresolution. We can state that the students held neither sophisticated nor naïve beliefs in terms of singularity of truth.

\section{Findings about the Second Research Question: What are the FLL Beliefs of University Students?}

Learners' FLL beliefs collected by Horwitz's (1988) BALLI are presented below. The findings of each area of the BALLI were presented separately, and the percentage, mean scores, standard deviations for each items were presented in tables. The total percentages of disagreement (Strongly Disagree, Disagree) and agreement (Strongly Agree, Agree) were shown in the tables. The BALLI items were assessed individually not on the basis of a total score, as the BALLI does not provide a total score; rather individual items yields FLL conceptions of discrete students (Horwitz, 1988). Therefore, the full items were presented in the tables below. 


\section{Learners' Beliefs about Difficulty of FLL}

The university students' beliefs about the difficulty of FLL were presented in table two separate tables (table 4 and 5). The results for the item 4, which measures the learners' difficulty perception of English and item 14, which asks for learners' opinions about the time needed for fluency in English were presented in a separate section as they had different response scales.

\section{Table 4}

Learners' Beliefs about Difficulty of FLL

\begin{tabular}{|c|c|c|c|c|c|c|c|}
\hline Items* & $\mathrm{N}$ & $\bar{X}$ & $\mathrm{Sd}$ & $\begin{array}{l}(\%) \\
\text { SD/D } \\
(1,2) \\
\end{array}$ & $\begin{array}{l}(\%) \\
\text { NI } \\
(3) \\
\end{array}$ & $\begin{array}{l}(\%) \\
\text { A/SA } \\
(4,5) \\
\end{array}$ & $\begin{array}{l}\text { Level of } \\
\text { Agreement }\end{array}$ \\
\hline $\begin{array}{l}\text { 3. Some languages are easier } \\
\text { to learn than the others. }\end{array}$ & 302 & 3,86 & 1.09 & 12,3 & 13,9 & 73,8 & Agree \\
\hline $\begin{array}{l}\text { 6. I believe that I will } \\
\text { ultimately learn to speak this } \\
\text { language very well. }\end{array}$ & 302 & 3,51 & 1.16 & 21,2 & 20,5 & 58,03 & Agree \\
\hline $\begin{array}{l}\text { 24. It is easier to speak than } \\
\text { understand a foreign } \\
\text { language. }\end{array}$ & 302 & 3,06 & 1.13 & 32,1 & 29,8 & 38,0 & NI \\
\hline $\begin{array}{l}\text { 28. It is easier to read and } \\
\text { write this language than to } \\
\text { speak and understand it. }\end{array}$ & 302 & 3,19 & 1.21 & 28,8 & 27,8 & 43,4 & NI \\
\hline
\end{tabular}

As the results suggest, most of the students $(73,8 \%)$ supported the idea that some languages can be learned easier than the others (item 3). That is, the participants believed that the difficulty of FLL differs depending on the language being learned. Likewise, the result for the item $6(58,03 \%)$ showed that the students generally believed that they would finally speak English quite good. That is, they were self-confident enough that they could learn English in the long view. About the difficulty of English, $46 \%$ of the participants rated that the language they tried to learn (English) was of medium difficulty. The percentage of those who viewed English as a difficult language was 23, $5 \%$. As for duration of learning a foreign language, the mean score $(M=2,68)$ pointed out a middle length of time. For this item, 30, $8 \%$ reported that 3-5 years were needed to be fluent in 
The Relationship between University Students' Epistemological and Foreign Language Learning Beliefs

the language. As an approximate finding to that, 29, $5 \%$ thought that "1-2 years" would be enough for fluency. The scores for the $24^{\text {th }}$ item $(M=3,06)$ and the $28^{\text {th }}$ item $(M=3,19)$ revealed that the learners mostly were undecided.

\section{Table 5}

Beliefs about Difficulty of English and Duration for Fluency

\begin{tabular}{|c|c|c|c|c|c|c|c|c|}
\hline Items & $\mathrm{N}$ & $\bar{X}$ & Sd. & 1 & 2 & 3 & 4 & 5 \\
\hline $\begin{array}{l}\text { 4. The language I am trying to } \\
\text { learn is: (1)very difficult, } \\
\text { (2)difficult,(3)medium } \\
\text { difficulty,(4)easy, (5) very easy }\end{array}$ & 302 & 2,79 & .97 & 10,6 & 23,5 & 46,0 & 15,6 & 4,3 \\
\hline $\begin{array}{l}\text { 14. If someone spends one } \\
\text { hour a day learning a language, } \\
\text { how long would it take him/her } \\
\text { to become fluent? (1) less than } \\
\text { a year, (2) } 1-2 \text { years, (3) } 3-5 \\
\text { years, (4) 5-10 years, (5) you } \\
\text { cannot learn a language in } 1 \\
\text { hour a day }\end{array}$ & 302 & 2,68 & 1.22 & 17,9 & 29,5 & 30,8 & 9,6 & 12,3 \\
\hline
\end{tabular}

\section{Learners' Beliefs about FLL Aptitude}

Table 5 shows the university students' beliefs about the FLL Aptitude dimension of the BALLI. This factor includes nine items.

It is obviously seen that the participants were generally undecided about majority of the statements of FLL Aptitude dimension. That is, they were generally indecisive about the role of aptitude in FLL. The students agreed on the item $1(77,8 \%)$, namely, the superiority of children over adults and the item 34 $(83,1 \%)$, which proposes that everyone has the potential to speak a target language. The learners' agreement on the item 1 indicates that they believed in importance of early exposure and encounter to foreign language. Their agreement on the item 34 reveals that the students did not associate FLL with aptitude. The only item that the participants disagreed was the $29^{\text {th }}$ item $(M=2,54)$, which moots the idea that people, who have a good grasp of maths and science are also good in FLL. More than half $(55,3 \%)$ rated they are talented in learning a foreign language. However, as the mean $(M=3,34)$ for this statement (item 15) implies many learners disagreed $(25,2 \%)$ or were neutral $(19,5 \%)$. Likewise, there wasn't a consensus on the idea that some individuals has a natural gift given to 


\section{Mehmet Emin MUNIS}

them in FLL $(M=2,95)$ and speaking more than one language is an indicator of intelligence as item 2 and 32 respectively suggest.

Table 6

Learners' Beliefs about FLL Aptitude

\begin{tabular}{|c|c|c|c|c|c|c|c|}
\hline Items & $\mathrm{N}$ & $\bar{X}$ & Sd & $\begin{array}{l}(\%) \\
\mathrm{SD} / \mathrm{D} \\
(1,2)\end{array}$ & $\begin{array}{l}(\%) \\
\text { NI } \\
(3)\end{array}$ & $\begin{array}{l}(\%) \\
\text { A/SA } \\
(4,5)\end{array}$ & $\begin{array}{l}\text { Level of } \\
\text { Agreement }\end{array}$ \\
\hline $\begin{array}{l}\text { 1. It is easier for children than } \\
\text { adults to learn a foreign } \\
\text { language. }\end{array}$ & 302 & 4,03 & 1.22 & 14,6 & 7,6 & 77,8 & Agree \\
\hline $\begin{array}{l}\text { 2. Some people are born with } \\
\text { a special ability which helps } \\
\text { them learn a foreign } \\
\text { language. }\end{array}$ & 302 & 2,95 & 1.18 & 39,7 & 23,8 & 36,5 & NI \\
\hline $\begin{array}{l}\text { 10. It is easier for someone } \\
\text { who already speaks a foreign } \\
\text { language to learn another } \\
\text { one. }\end{array}$ & 302 & 3,27 & 1.15 & 27,8 & 25,8 & 46,4 & NI \\
\hline $\begin{array}{l}\text { 15. I have a foreign language } \\
\text { aptitude. }\end{array}$ & 302 & 3,34 & 1.18 & 25,2 & 19,5 & 55,3 & NI \\
\hline $\begin{array}{l}\text { 22. Women are better than } \\
\text { men at learning foreign } \\
\text { languages. }\end{array}$ & 302 & 2,83 & 1.11 & 34,1 & 43,1 & 22,8 & NI \\
\hline $\begin{array}{l}\text { 29. People who are good at } \\
\text { math and science are good at } \\
\text { learning foreign languages. }\end{array}$ & 302 & 2,54 & 1.05 & 44,4 & 41,4 & 14,2 & Disagree \\
\hline $\begin{array}{l}\text { 32. People who speak more } \\
\text { than one language well are } \\
\text { very intelligent. }\end{array}$ & 302 & 3,21 & 1.23 & 32,8 & 19,9 & 47,4 & NI \\
\hline $\begin{array}{l}\text { 33. Turkish people are good } \\
\text { at learning foreign languages. }\end{array}$ & 302 & 2,85 & 1.11 & 34,8 & 39,1 & 26,1 & NI \\
\hline $\begin{array}{l}\text { 34. Everyone can learn to } \\
\text { speak a foreign language. }\end{array}$ & 302 & 4,07 & 1.14 & 11,6 & 5,3 & 83,1 & Agree \\
\hline
\end{tabular}

\section{Learners' Beliefs about the Nature of FLL}

The university students' beliefs about the Nature of FLL dimension of the BALLI were displayed in table 7 below. The factor consists of seven items. 
The Relationship between University Students' Epistemological and Foreign Language Learning Beliefs

Table 7

Learners' Beliefs about the Nature of FLL

\begin{tabular}{|c|c|c|c|c|c|c|c|}
\hline Items & $\mathrm{N}$ & $\bar{X}$ & $\mathrm{Sd}$ & $\begin{array}{l}(\%) \\
\mathrm{SD} / \mathrm{D} \\
(1,2)\end{array}$ & $\begin{array}{l}(\%) \\
\text { NI } \\
(3)\end{array}$ & $\begin{array}{l}(\%) \\
\text { A/SA } \\
(4,5)\end{array}$ & $\begin{array}{l}\text { Level of } \\
\text { Agreement }\end{array}$ \\
\hline $\begin{array}{l}\text { 5. The language I am } \\
\text { trying to learn is } \\
\text { structured in the } \\
\text { same way as } \\
\text { Turkish. }\end{array}$ & 302 & 2,50 & 1.29 & 59,6 & 12,9 & 27,5 & Disagree \\
\hline $\begin{array}{l}\text { 8. It is necessary to } \\
\text { know the foreign } \\
\text { culture in order to } \\
\text { speak the foreign } \\
\text { language. }\end{array}$ & 302 & 2,95 & 1.28 & 43,7 & 16,9 & 39,4 & NI \\
\hline $\begin{array}{l}\text { 11. It is better to } \\
\text { learn a foreign } \\
\text { language in the } \\
\text { foreign country. }\end{array}$ & 302 & 3,80 & 1.30 & 20,5 & 8,6 & 70,9 & Agree \\
\hline $\begin{array}{l}\text { 16. Learning a } \\
\text { foreign language is } \\
\text { mostly a matter of } \\
\text { learning many new } \\
\text { vocabulary words. }\end{array}$ & 302 & 3,94 & 1.08 & 11,6 & 9,3 & 79,1 & Agree \\
\hline $\begin{array}{l}20 \text {. Learning a } \\
\text { foreign language is } \\
\text { mostly a matter of } \\
\text { learning many } \\
\text { grammar rules. }\end{array}$ & 302 & 3,40 & 1.19 & 22,8 & 23,2 & 54 & Agree \\
\hline $\begin{array}{l}25 . \quad \text { Learning a } \\
\text { foreign language is } \\
\text { different from } \\
\text { learning other } \\
\text { school subjects. }\end{array}$ & 302 & 3,62 & 1.12 & 16,6 & 17,2 & 66,2 & Agree \\
\hline $\begin{array}{l}26 . \quad \text { Learning a } \\
\text { foreign language is } \\
\text { mostly a matter of } \\
\text { translating from } \\
\text { English. }\end{array}$ & 302 & 3,70 & 1.07 & 16,2 & 13,6 & 70,2 & Agree \\
\hline
\end{tabular}

The remarkable results about this dimension of language learning were that the participants viewed learning English as a matter of learning many new words 


\section{Mehmet Emin MUNIS}

(the $16^{\text {th }}$ item: $79,1 \%$ ), grammar rules (the $20^{\text {th }}$ item: $54 \%$ ), and translating from English (the $26^{\text {th }}$ item: $70,2 \%$ ). These findings indicate that the students minded these aspects in their FLL process. Not surprisingly, most of the participants (70, 9) reported that learning the language in a foreign country as a better way of learning (item 11). However, about the necessity of getting familiar with the foreign culture so as to speak the language, the participants seemed to be uncertain $(M=2,95$; item 8$)$.

\section{Learners' Beliefs about Learning and Communication Strategies}

This dimension has eight items. The Learning Strategies section consists of the item 17 and 21, whereas the Communication Strategies section has item 7 , $9,12,13,18$, and 19 . The outcomes of this factor are presented below in table 4.8 .

The students were willing to communicate by means of the target language. For example, the result for the item $12^{\text {th }}(70,2 \%)$ displayed they sensed the importance using the language and that their eagerness to speak the language. Likewise, the proportion of disagreement $(58,9 \%)$ for the $18^{\text {th }}$ item demonstrated that many participants had self-confidence in speaking English, though $28 \%$ reported they would feel timid. Similarly, one of the statement (item 9) that the learners disagreed $(69,5 \%)$ was that one shouldn't speak in the target language until he/she can utter the language items correctly can be regarded as they attached importance to practice rather than accuracy. However, the result of the $7^{\text {th }}$ item $(62,6 \%)$ shows they attach importance to speaking a foreign language properly with a perfect accent. Although the mean score for the $13^{\text {th }}$ item $(M=3,20)$ pointed out to an indecision about guessing unknown vocabulary, the percentage of agreement (48\%) demonstrated that many learners were in favour of predicting unknown vocabulary. The findings regarding learning strategies, the $17^{\text {th }}$ item $(86,7 \%)$ and $21^{\text {st }}$ item $(60,6 \%)$ displayed that the learners valued the usage and practice of the language as they agreed on the both statements. 
The Relationship between University Students' Epistemological and Foreign Language

Learning Beliefs

\section{Table 8}

Learners' Beliefs about Learning and Communication Strategies

\begin{tabular}{|c|c|c|c|c|c|c|c|}
\hline Items & $\mathrm{N}$ & $\bar{X}$ & $\mathrm{Sd}$ & $\begin{array}{l}(\%) \\
\mathrm{SD} / \mathrm{D} \\
(1,2)\end{array}$ & $\begin{array}{l}(\%) \\
\mathrm{N}(3)\end{array}$ & $\begin{array}{l}(\%) \\
\mathrm{A} / \mathrm{SA} \\
(4,5)\end{array}$ & $\begin{array}{l}\text { Level of } \\
\text { Agreement }\end{array}$ \\
\hline $\begin{array}{l}\text { Learning Strategies } \\
\text { 17. It is important to repeat } \\
\text { and practise often. }\end{array}$ & 302 & 4,25 & 1.08 & 9,3 & 4,0 & 86,7 & $\begin{array}{l}\text { Strongly } \\
\text { Agree }\end{array}$ \\
\hline $\begin{array}{l}\text { 21. It is important to practise } \\
\text { in the language laboratory. } \\
\text { Communication Strategies }\end{array}$ & 302 & 3,59 & 1.10 & 15,2 & 24,2 & 60,6 & Agree \\
\hline $\begin{array}{l}\text { 7. It is important to speak a } \\
\text { foreign language with an } \\
\text { excellent accent. }\end{array}$ & 302 & 3,53 & 1.23 & 25,8 & 11,6 & 62,6 & Agree \\
\hline $\begin{array}{l}\text { 9. You should say nothing in } \\
\text { the foreign language until you } \\
\text { say it correctly. }\end{array}$ & 302 & 2,23 & 1.19 & 69,5 & 11,9 & 18,6 & Disagree \\
\hline $\begin{array}{l}\text { 12. If I heard someone } \\
\text { speaking the language I am } \\
\text { trying to learn, I would go up } \\
\text { to them so that I could practise } \\
\text { speaking the language. }\end{array}$ & 302 & 3,63 & 1.12 & 16,9 & 12,9 & 70,2 & Agree \\
\hline $\begin{array}{l}\text { 13. It is ok to guess if you do } \\
\text { not know a word in the foreign } \\
\text { language. }\end{array}$ & 302 & 3,20 & 1.19 & 29,5 & 22,5 & 48,0 & NI \\
\hline $\begin{array}{l}\text { 18. I feel self-conscious } \\
\text { speaking the foreign language } \\
\text { in front of other people. }\end{array}$ & 302 & 2,60 & 1.26 & 58,9 & 12,6 & 28,5 & NI \\
\hline $\begin{array}{l}\text { 19. If you are allowed to make } \\
\text { mistakes in the beginning, it } \\
\text { will be hard to get rid of them } \\
\text { later on. }\end{array}$ & 302 & 2,99 & 1.29 & 40,1 & 19,9 & 40,0 & NI \\
\hline
\end{tabular}

\section{Learners' Beliefs about Motivations and Expectations}

The participants' beliefs regarding this dimension of the BALLI were introduced in table 9. The factor consists of four items. 
Mehmet Emin MUNIS

Table 9

Learners' Beliefs about Motivations and Expectations

\begin{tabular}{|c|c|c|c|c|c|c|c|}
\hline Items & $\mathrm{N}$ & $\bar{X}$ & $\mathrm{Sd}$ & $\begin{array}{l}(\%) \\
\mathrm{SD} / \mathrm{D} \\
(1,2) \\
\end{array}$ & $\begin{array}{l}(\%) \\
\text { NI } \\
(3)\end{array}$ & $\begin{array}{l}(\%) \\
\mathrm{A} / \mathrm{SA} \\
(4,5)\end{array}$ & $\begin{array}{l}\text { Level of } \\
\text { Agreement }\end{array}$ \\
\hline $\begin{array}{l}\text { 23. If I speak this language } \\
\text { very well, I will have many } \\
\text { opportunities to use it. }\end{array}$ & 302 & 3,96 & 1.13 & 12,3 & 11,6 & 76,1 & Agree \\
\hline $\begin{array}{l}27 \text {. If I learn to speak this } \\
\text { language very well, it will help } \\
\text { me get a good job. }\end{array}$ & 302 & 4,11 & 1.04 & 8,6 & 10,6 & 80,8 & Agree \\
\hline $\begin{array}{l}30 \text {. Turkish people think that it } \\
\text { is important to speak a foreign } \\
\text { language. }\end{array}$ & 302 & 3,58 & 1.03 & 13,9 & 26,5 & 59,6 & Agree \\
\hline $\begin{array}{l}31 \text {. I would like to learn this } \\
\text { language so that I can get to } \\
\text { know the speakers better. }\end{array}$ & 302 & 3,33 & 1.16 & 28,1 & 19,9 & 52,0 & NI \\
\hline
\end{tabular}

The overall outcomes of the dimension revealed that the students were generally motivated and had positive expectations about learning and speaking English. The table indicates that $76,1 \%$ of the students believed that they will encounter a lot of opportunities if they speak English well (the item 23) and it will be helpful for them get a good job (the item $27^{\text {th }}: 80,8 \%$ ). According to the finding of the $30^{\text {th }}$ item, $59,6 \%$ thought Turkish people believe that speaking a foreign language other than their native language is significant. The only item that the participants seemed to be neutral according to the mean score $(M=3,33)$ was the $31^{\text {st }}$ item. However, $52 \%$ of the participants agreed on that they desired to learn English in order to get the speakers of it better.

\section{Findings about the Fourth Research Question: Is There a Difference in Epistemological and FLL Beliefs of University Students in terms of Gender?}

In order to reveal whether males and females vary in their epistemological and FLL beliefs, independent sample t-test was used. P- Value was considered whether the difference was significant or not. 
The Relationship between University Students' Epistemological and Foreign Language Learning Beliefs

Table 10

Learners' EBs in terms of Gender (t-Test)

\begin{tabular}{|c|c|c|c|c|c|c|c|}
\hline Scale & Dimension & Gender & $\mathrm{N}$ & $\bar{X}$ & $\mathrm{Sd}$ & $\mathrm{t}$ & $\mathrm{p}$ \\
\hline \multirow{8}{*}{ 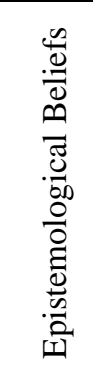 } & \multirow{2}{*}{$\begin{array}{l}\text { Learning depends } \\
\text { on effort }\end{array}$} & $\mathrm{F}$ & 157 & 36,32 & 9,40 & \multirow{2}{*}{1,142} & \multirow{2}{*}{,255 } \\
\hline & & $\mathrm{M}$ & 145 & 37,64 & 10,65 & & \\
\hline & \multirow{2}{*}{$\begin{array}{l}\text { Learning depends } \\
\text { on ability }\end{array}$} & $\mathrm{F}$ & 157 & 18,49 & 5,63 & \multirow{2}{*}{2,201} & \multirow{2}{*}{, $029 *$} \\
\hline & & M & 145 & 19,92 & 5,68 & & \\
\hline & \multirow{2}{*}{$\begin{array}{l}\text { There is only one } \\
\text { truth }\end{array}$} & $\mathrm{F}$ & 157 & 28,61 & 5,46 & \multirow{2}{*}{0,290} & \multirow{2}{*}{,772 } \\
\hline & & M & 145 & 28,80 & 5,45 & & \\
\hline & \multirow[t]{2}{*}{ Total } & $\mathrm{F}$ & 157 & 83,43 & 13,35 & \multirow{2}{*}{1,891} & \multirow[t]{2}{*}{ 600 } \\
\hline & & M & 145 & 86,36 & 13,58 & & \\
\hline
\end{tabular}

$* \mathrm{p}<.05$

Table 11 reveals that university students' EBs do not significantly vary in terms of gender regarding the subdimensions that learning depends on effort and that only one truth ( $\mathrm{p}>.05)$. It can be stated that both males and females participated in this study had similar EBs in terms of the mentioned dimensions of EBs scale. However, the p-value for learning depends on ability factor was $\mathrm{p}<$ .05 . This finding shows a significant difference between males and females. The mean scores of the males $(M=19,92)$ and females $(M=18,49)$ of this subcategory show that females' mean score is smaller a bit. According to the EBQ, smaller mean scores indicate more sophisticated epistemic beliefs. Therefore, we can deduce that the female participating in this study had slightly more sophisticated beliefs in terms of the effect of ability in learning. That is, the females were less inclined to evaluate learning as a matter of ability. 
Mehmet Emin MUNIS

\section{Table 11}

Learners' FLL in terms of Gender ( $\mathrm{t}$ - Test)

\begin{tabular}{|c|c|c|c|c|c|c|c|}
\hline Scale & Dimension & Gender & $\mathrm{N}$ & $\bar{X}$ & $\mathrm{Sd}$ & $\mathrm{t}$ & $\mathrm{p}$ \\
\hline \multirow{12}{*}{ 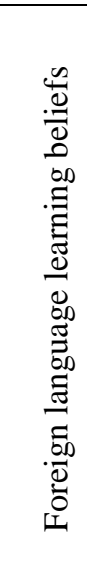 } & \multirow{2}{*}{$\begin{array}{l}\text { Difficulty of } \\
\text { language learning }\end{array}$} & $\mathrm{F}$ & 157 & 19,29 & 2,46 & \multirow{2}{*}{1,124} & \multirow{2}{*}{,262 } \\
\hline & & M & 145 & 18,92 & 3,30 & & \\
\hline & \multirow{2}{*}{$\begin{array}{l}\text { Foreign language } \\
\text { aptitude }\end{array}$} & $\mathrm{F}$ & 157 & 29,55 & 4,63 & \multirow{2}{*}{$-1,507$} & \multirow{2}{*}{,133 } \\
\hline & & M & 145 & 28,70 & 5,17 & & \\
\hline & \multirow{2}{*}{$\begin{array}{l}\text { The nature of } \\
\text { language learning }\end{array}$} & $\mathrm{F}$ & 157 & 24,05 & ,359 & \multirow{2}{*}{,- 454} & \multirow{2}{*}{,650 } \\
\hline & & M & 145 & 23,83 &, 316 & & \\
\hline & \multirow{2}{*}{$\begin{array}{l}\text { Learning } \\
\& \text { communication } \\
\text { strategies }\end{array}$} & $\mathrm{F}$ & 157 & 26,38 & 4,09 & \multirow[b]{2}{*}{,- 1023} & \multirow[b]{2}{*}{,307 } \\
\hline & & M & 145 & 25,85 & 4,94 & & \\
\hline & \multirow{2}{*}{$\begin{array}{l}\text { Motivations and } \\
\text { expectations }\end{array}$} & $\mathrm{F}$ & 157 & 15,16 & 2,78 & \multirow{2}{*}{$-1,030$} & \multirow{2}{*}{,304 } \\
\hline & & M & 145 & 14,82 & 3,02 & & \\
\hline & \multirow{2}{*}{ Total } & $\mathrm{F}$ & 157 & 114,45 & 12,80 & \multirow{2}{*}{$-1,384$} & \multirow{2}{*}{, 167} \\
\hline & & M & 145 & 112,13 & 16,28 & & \\
\hline
\end{tabular}

*p $>.05$

Table 11 indicates the findings in relation to the learners' FLL beliefs in terms of gender. The students' FLL beliefs did not differ significantly in terms of gender; they had similar language beliefs in general and based on the subcategories ( $p>.05)$.

\section{Findings about the third Research Question: Is There a Significant Relationship between the EBs and FLL Beliefs of University Students?}

The correlation between the students' epistemological and FLL beliefs was determined by Pearson correlation coefficient. According to the results, there was a slight correlation between epistemological and FLL beliefs of the students ( $\mathrm{r}=$ $-0.181, \mathrm{p}<.005)$.

\section{CONCLUSION AND DISCUSSION}

This study aimed to reveal the epistemological and FLL beliefs of university students and whether a correlation between them exists or not. The findings demonstrated that the university students held a range of epistemic and FLL beliefs. The result also revealed that the correlation between epistemological and FLL beliefs of the participants was negative and slight. According to the $\mathrm{EBQ}$, low scores show more developed epistemic beliefs while high scores show 
The Relationship between University Students' Epistemological and Foreign Language Learning Beliefs

less developed beliefs. We can state that as learners' EBs about acquiring knowledge become more sophisticated, they become more concerned and positive about their beliefs of FLL.

The university students held sophisticated EBs regarding their beliefs about the function of effort and ability in learning. Namely, the participants believed that one can learn anything if sufficient amount of effort is shown since learning is not a matter of ability. EBs have a significant role in learning as they may ease learning or hinder it (Schommer \& Walker, 1995). Students considering learning a matter of ability would probably not spend much time for studying. When students hold more sophisticated beliefs, they perform better in tasks and text comprehension; they get better scores and are more successful regarding academic achievement (Ryan, 1984; Schommer, 1990, 1992, 1993; Schommer et al., 1997; Cano, 2005). In this sense, believing that learning is associated with effort is significant in FLL learning, too. Learners who regard learning as a matter of effort will normally study harder for learning the target language. When we take into consideration that FLL is a long process, students will need studying hard, insistence and perseverance in order to proceed in FLL. Those who found out the importance of effort in learning, can show perseverance better and cope with the difficulties arising during the process of FLL more successfully.

The participants' uncertainty about multiplicity of truths means that although they held the belief that some truths might change, they also believed that there might be absolute truths. Some studies put forth similar findings parallel to our study, as well (Eren, 2007; Özdemir, 2013; Kazu \& Erten, 2015). The reasons behind the uncertainty of the participants about one singularity of truth is probably associated with various factors such as previous education, gender, teachers, family, environment and age (Walker et al., 2009). The students probably were more dependent on teachers and course books in acquiring knowledge and started to believe the knowledge they attained from books and teachers were unquestionable. When the belief in fixed knowledge is weaker, learners tend to have better cognitive abilities; they are more open-minded and more tolerant to opposite opinions (Chan et al., 2011). Therefore, it is significant to enlighten students about EBs. Considering language learners who are unsure about multiplicity of knowledge will probably be confused about making the right decisions related to FLL or deciding on the right strategies in FLL process as a learner's decision making and strategy selection may be affected by his/her Ebs. In other word, Ebs affect learners' decisions in FLL and the strategies they pursue during their learning process. The uncertainty of the participants about multiplicity of truths may also be an indicator of intolerance of ambiguity, which 


\section{Mehmet Emin MUNIS}

is a disadvantage in FLL and may interfere with FLL process. Individuals who are intolerant of ambiguity tended to be stricter and they look for certainty (Kimura, 2016). The students participating in this study probably may have difficulties when they find out that some pieces of the language are complex or not structured the same as their native language since they were not decided about the changeability of knowledge.

The study showed that university students held numerous beliefs about FLL. This confirms the approval that "learners and teachers bring with them to class a set of beliefs and expectations" (Hall, 2011: 17). Nearly half of the participants considered English a language of medium difficulty and around onethird in total thought it is a difficult or a very difficult language. Studies conducted in different contexts also yielded similar results (Bernat and Lloyd, 2007; Başaran, 2010; Geyimci, 2015). For the needed time to speak English fluently, about one-third of the participants reported that one would need 3-5 years, while around one-third thought 1-2 years would be needed. This finding was also consistent with the results of some other studies (Bernat \& Lloyd, 2007). Horwitz (1988) points out that an inconsistency between students' anticipations and the realities in FLL may cause disappointment and may end up with negative outcomes. In this sense, the participants' perception of difficulty seemed to be consonant with their opinion about the needed time for speaking English fluently.

The learners agreed with the idea that everyone can learn a foreign language also in accordance with their EBs. The finding approves Horwitz (1988) and Yalçın's (2013) studies. Having a positive concept of language aptitude is surely important; when learners believe that they lack the capacity needed to learn a language, they may do poor in FLL (Horwitz, 1988). The participants overwhelmingly believed in the importance of repetition and practice. Altan (2006), Büyükyazı (2010) and Suwanarak (2012) also found similar results. The findings show that they appreciated rote learning. As for communication strategies, the students generally were willing to practise with people who speak English. Majority of the learners agreed with the importance of speaking perfectly, but they rejected the idea that someone should not say anything until it is expressed correctly. Apparently, they did not let accuracy be an obstacle that prevents them from speaking in the early phase of learning. This is important since having beliefs that emphasize the significance of accuracy may cause anxiety (Horwitz, Horwitz, and Cope 1986; Horwitz, 1988).

The study also aimed to show the effects of gender on epistemological and FLL beliefs of the participants. We found out that although gender is not a variable for FLL beliefs, the EBs differ in terms of gender. The results revealed 
The Relationship between University Students' Epistemological and Foreign Language Learning Beliefs

that the males and females' epistemic beliefs did not differ significantly in terms of effort and only one truth dimensions of the EBQ. However, concerning ability dimension, it was found that females had slightly more developed epistemic beliefs. That is, female students supported the belief that learning is not a matter of ability a little stronger than males, though it was a small difference. In terms of learning depends on effort and ability dimensions Deryakulu and Büyüköztürk (2005) Walker et al., (2009), Özdemir (2013) and Arslantaş (2016) found that females held more sophisticated beliefs. Therefore, it can be deduced from the findings that gender is a factor on epistemic beliefs, and female learners seem to have more developed EBs than males in terms of effort dimension. In another study in the field of EBs, pre-service teachers' EBs studying at Physical Education program at a Turkish university were investigated by Güngör (2016). The study reported that teacher candidates had sophisticated EBs with regard to all three dimensions of the EBQ.

Many participants believed that English language is a language of medium difficulty, and they believed that they can learn it well. Considering that the learners believed that learning can be realized with effort, these beliefs seem to be reasonable and it can be stated that they can learn the language provided that they study hard in accordance with their EBs. Parallel to their belief in the role of effort in general learning, students also thought that effort is significant in learning a foreign language rather than aptitude. Their beliefs in practice and repetition $(86,7 \%)$ and willingness to go to speak to someone speaking the language for practising it $(70,2 \%)$ were consonant with their EBs as they showed students' willingness to strive for learning a foreign language. Learners who believed that success is not associated with effort were less eager to communicate (Mori, 1999). In this regard, the willingness of the learners in this study for communicating in English can be attributed to their sophisticated epistemic beliefs associated with their belief that learning depends on effort. Considering the overall results, it can be stated that learners' FLL may be related to their EBs.

Training learners to promote their EBs from the very beginning of their education up to university will help them realize a successful FLL process. University students should be encouraged share their beliefs regarding both epistemological and foreign language beliefs so that they can be aware of their positive and negative beliefs. 


\section{Mehmet Emin MUNIS}

\section{RECOMMENDATIONS FOR FURTHER STUDIES}

More studies are needed regarding FLL beliefs and students' personal epistemology. More comprehensive and long-term research can be done with the aim of revealing the effects of language learners' epistemic beliefs on their FLL beliefs and the results of these possible impacts. Likewise, varied kinds of data can be collected and different variables can be examined. The link between language learners' academic achievement and their both epistemic and FLL beliefs can be investigated.

\section{REFERENCES}

Altan, M. X. (2006). Beliefs about language learning of foreign language-major university students. Australian Journal of Teacher Education, 31(2), 5.

Al-Zubaidi, K. O. \& Sazalli, N. A. H. (2012). The language learning beliefs of Arab ESL Students. In UNNES International Conference on ELTLT (English Language Teaching, Literature, and Translation) (pp. 32-43).

Arslantaş, H. A. (2016). Epistemological beliefs and academic achievement. Journal of Education and Training Studies, 4(1), 215-220.

Bahadir, P. (2011). The Relationship Between EFL Learners' Beliefs and EFL Teachers' Beliefs on Language Learning and the Effect of Learners' Beliefs on Learner Performance: Metacognitive Awareness. Master thesis, Çanakkale Onsekiz Mart University.

Barcelos, A. M. F. (2000). Understanding Teachers' and Students' Language Learning Beliefs in Experience: A Deweyan Approach. Doctoral Dissertation, University of Alabama.

Başaran, S. (2010). Effects of Podcasts on Language Learning Beliefs and SelfEfficacy Perceptions of First-Year Turkish University Students. Doctoral dissertation. Çukurova University.

Bernat, E. \& Gvozdenko, I. (2005). Beliefs about language learning: Current knowledge, pedagogical implications, and new research directions. TESLEJ, 9(1), 1-21.

Bernat, E. \& Lloyd, R. (2007). Exploring the gender effect on EFL learners' beliefs about language learning. Australian Journal of Educational \& Developmental Psychology, 7(1), 79-91. 
The Relationship between University Students' Epistemological and Foreign Language Learning Beliefs

Büyükyaz1, M. (2010). The beliefs of university foreign language students and their teachers about language learning. Celal Bayar Üniversitesi Sosyal Bilimler Enstitüsü Dergisi, 8(1), 169-182.

Cano, F. (2005). Epistemological beliefs and approaches to learning: Their change through secondary school and their influence on academic performance. British Journal of Educational Psychology, 75(2), 203-221.

Chan, K. W. \& Elliott, R. G. (2004). Epistemological beliefs across cultures: Critique and analysis of beliefs structure studies. Educational Psychology, 24(2), 123-142.

Chan, N. M., Ho, I. T. \& Ku, K. Y. (2011). Epistemic beliefs and critical thinking of Chinese students. Learning and Individual Differences, 21(1), 67-77.

Cisdık, Z.K. (2014). Exploring the Changes in Turkish University Students' Language Learning Beliefs as a Result of 'Erasmus Student Mobility for Studies Programme'. MA thesis, Çukurova University.

Cotterall, S. (1995). Readiness for autonomy: Investigating learner beliefs. System, 23(2), 195- 205.

Daif-Allah, A.S. (2012). Beliefs about foreign language learning and their relationship to gender. English Language Teaching, 5(10), 20-33.

Deryakulu, D. \& Büyüköztürk, Ş. (2002). Epistemolojik inanç ölçeğinin geçerlik ve güvenirlik çalışması. Eğitim Araştırmaları, 8, 111-125.

Deryakulu, D. \& Büyüköztürk, Ş. (2005). Epistemolojik inanç ölçeğinin faktör yapısının yeniden incelenmesi: Cinsiyet ve öğrenim görülen program türüne göre epistemolojik inançların karşılaştırılması. Eğitim Araştırmalarl, 18, 57-70.

Dinçer, A. (2017). EFL learners' beliefs about speaking English and being a good speaker: A metaphor analysis. Universal Journal of Educational Research, 5(1), 104-112.

Ekinci, N. (2017). Examining the Relationships between Epistemological Beliefs and Teaching and Learning Conceptions of Lower-Secondary Education Teachers. Inönü University Journal of the Faculty of Education, 18(1), 344-358. http://dx.doi.org/10.17679/inuefd.307065

Eren, A. (2007). Examining the differences among undergraduate students' epistemological beliefs. Eğitim ve Bilim - Educationand Science, 32(145), 71-85. 


\section{Mehmet Emin MUNIS}

Fujiwara, T. (2011). Language learning beliefs of Thai EFL university students:

Dimensional structure and cultural variations. Electronic Journal of Foreign Language Teaching, 8(1), 87-107

Geyimci, G. (2015). Beliefs About Language Learning and Language Learning Strategy Use in an EFL Context. Master thesis, Çă̆ University.

Güngör, N.B. (2016). Beden Eğitimi Öğretmen Adaylarının Epistemolojik Inançları ile Liderlik Özellikleri Arasındaki Ilişkinin Incelenmesi. Master thesis, Gazi Üniversitesi.

Hall, G. (2011). Exploring English Language Teaching: Language in Action. Roudledge.

Hofer, B. K. \& Bendixen, L. D. (2012). Personal epistemology: Theory, research, and future directions. APA Educational Psychology Handbook, 1, 227256.

Hofer, B. K. \& Pintrich, P. R. (1997). The development of epistemological theories: Beliefs about knowledge and knowing and their relation to learning. Review of Educational Research, 67(1), 88-140.

Hofer, B.K. (1999). Instructional context in the college mathematics classroom: Epistemological beliefs and student motivation. J. Staff Prog. Org. Dev. 16(2), 73-82.

Horwitz, E. K. (1985). Using student beliefs about language learning and teaching in the foreign language methods course. Foreign Language Annals, 18(4), 333-340.

Horwitz, E. K. (1988). The beliefs about language learning of beginning university foreign language students. The Modern Language Journal, 72, 283-294.

Horwitz, E. K. (1999). Cultural and situational influences on foreign language learners' beliefs about language learning: A review of BALLI studies. System, 27(4), 557-576.

Horwitz, E. K., Horwitz, M. B. \& Cope, J. (1986). Foreign-Language Classroom Anxiety. Modern Language Journal, 70(2), 125-132.

Jehng, J. C. J., Johnson, S. D. \& Anderson, R. C. (1993). Schooling and students' epistemological belefs about learning. Contemporary Educational Psychology, 18,23-35. 
The Relationship between University Students' Epistemological and Foreign Language Learning Beliefs

Jennifer, M. Y. \& Park, Y. (2015). Investigating middle school students' beliefs about English language learning in the Korean EFL context. International Journal of Teaching, Education and Language Learning, 2 (4), 88-121.

Kardash, C. A. M. \& Scholes, R. J. (1996). Effects of pre-existing beliefs, epistemological beliefs, and need for cognition on interpretation of controversial issues. Journal of Educational Psychology, 88, 260-271.

Kazu, I.Y. \& Erten, P. (2015). Ögretmen adaylarının epistemolojik inanclarının incelenmesi [Investigation of pre-service teachers' epistemological beliefs]. Dicle Üniversitesi Ziya Gökalp Egitim Fakultesi Dergisi, 25, 5775.

Kern, R. G. (1995). Students' and teachers' beliefs about language learning. Foreign Language Annals, 28(1), 71-92.

Kimura, H. (2016). L2 Intolerance of ambiguity revisited: Toward a comprehensive understanding. Konin Language Studies, 4(2), 197-216.

Matsuura, H., Chiba, R. \& Hilderbrandt, P. (2001). Beliefs about learning and teaching communicative English in Japan. JALT Journal, 23(1), 67-82.

Moeller, A.K. \& Catalano, T. (2015). Foreign Language Teaching and Learning. University of Nebraska.

Naghdipour, B. (2014). Language Learner Beliefs in an English as a Lingua Franca (ELF) Context. Advances in Language and Literary Studies, 5(1), $22-30$

Nikitina, L. \& Furuoka, F.(2018). Dimensionality in Language learners' personal epistemologies. International Journal of Instruction, 11(1), 269-282.

Özdemir, İ. (2013). İlköğretim Ikinci Kademe Öğretmenlerinin Epistemolojik Inançları ile Yapılandırmacı Yaklaşıma Yönelik Tutumları Arasındaki Ilişki. Doctoral dissertation, Pamukkale University.

Özşaker, M., Canpolat, A. M. \& Yıldız, L. (2011). Beden eğitimi öğretmen adaylarının epistemolojik inançları ve benlik saygıları arasındaki ilişki. Beden Egitimi ve Spor Bilimleri Dergisi, 5(2), 155-164.

Pan, L. \& Block, D. (2011). English as a "global language" in China: An investigation into learners' and teachers' language beliefs. System, 39(3), 391-402. 


\section{Mehmet Emin MUNIS}

Peacock, M. (1999). Beliefs about language learning and their relationship to proficiency. International Journal of Applied Linguistics, 9(2), 247-265.

Perry, W. G., Jr. (1968). Patterns of Development in Thought and Values of Students in a Liberal Arts College: A Validation of a Scheme.

Perry, W.G. (1970). Forms of Intellectual and Ethical Development in the College yeArs: A Scheme. Holt, Rinehart \& Winston.

Pouratashia, M. Zhu, C. \& Zamani, A. (2018). Relationship among Students' Epistemological Beliefs, Achievement Motivation, and Academic Achievement: A Path model. Başkent University Journal of Education 5(1), 78-87.

Rad, N. (2010). Evaluation of English students' beliefs about learning english as foreign language: A case of Kerman Azad University. In ICT for Language Learning Conference Proceedings.

Ryan, M. P. (1984a). Conceptions of prose coherence: Individual differences in epistemological standards. Journal of Educational Psychology, 76(6), 1226-1238.

Sevgi, S. \& Armağan Öner, F. (2017). Turkish Elementary Pre-Service Teachers' Epistemological Beliefs. International Journal of Eurasia Social Sciences, $8(28)$.

Schommer, M. (1990). Effects of beliefs about the nature of knowledge on comprehension. Journal of Educational Psychology, 82, 498-504.

Schommer, M. (1993). Epistemological development and academic performance among secondary students. Journal of Educational Psychology, 85, 406411.

Schommer, M. \& Walker, K. (1995). Are epistemological beliefs similar across domains? Journal of Educational Psychology, 87, 424-432.

Schommer, M., Crouse, A. \& Rhodes, N. (1992). Epistemological beliefs and mathematical text comprehension: Believing it is simple does not make it so. Journal of educational psychology, 84(4), 435.

Suwanarak, K. (2012). English language learning beliefs, learning strategies and achievement of Masters students in Thailand. TESOL in Context, 3, 1-15. 
The Relationship between University Students' Epistemological and Foreign Language

Learning Beliefs

Şevik, M., Yalçın, A. \& Bostancıŏlu, F. (2018). Vocational school students' beliefs about foreign language learning. Mehmet Akif Ersoy Üniversitesi Eğitim Fakültesi Dergisi, 46, 325-343

Truitt, S. N. (1995). Anxiety and Beliefs about Language Learning: A Study of Korean University Students Learning English. Doctoral dissertation, University of Texas.

Walker, S., Brownlee, J., Lennox, S., Exley, B., Howells, K. \& Cocker, F. (2009). Understanding first year university students: Personal epistemology and learning. Teaching Education, 20(3), 243-256.

Mori. Y (1999). Epistemological beliefs and language learning beliefs: What do language learners believe about their learning? Language Learning, 49(3), 377-415.

Yalçın, G. Ç. (2013). Exploring Preparatory School EFL Learners' and Teachers' Beliefs about Language Learning. Master Thesis, Gazi University.

Yazıc1, İ. Ç. (2014). Beliefs about language learning: Gender related or not? Çukurova University Journal of Institute of Social Science, 23(1), 229-238.

Zhou, Z. (2018). On the relationship of students' English learning beliefs and learning strategy in the university. Journal of Language Teaching and Research, 9(1), 175-180.

Ziegler, N. E. (2015). English Language Learners' Epistemic Beliefs about Vocabulary Knowledge. Doctoral dissertation, University of Toledo. 